\title{
О ВОЗМОЖНОСТИ РАСШИРЕНИЯ ОТЕЧЕСТВЕННОЙ КОМПОНЕНТНОЙ БАЗЫ ИСТОЧНИКОВ ТОКА НА ОСНОВЕ ЭНЕРГЕТИЧЕСКИХ КОНДЕНСИРОВАННЫХ СИСТЕМ
}

\author{
В.В. Просянюк, И. С. Суворов, Н.В. Прудников, С. В. Гильберт, Д. С. Зюзина \\ ВЯЧЕСЛАВ ВАСИЛЬЕВИЧ ПРОСЯНЮК - к.т.н., начальник отдела АО «ФНПЦ «НИИ прикладной химии». \\ Область научных интересов: пиротехнические источники электрического тока, устройства и системь \\ пиротехнической автоматики.
}

\begin{abstract}
ИВАН СТЕПАНОВИЧ СУВОРОВ - к.т.н., ведущчий научный сотрудник АО «ФНПЦ «НИИ прикладной химии». Область научных интересов: малогазовые пиротехнические составы и технология формования зарядов на их основе для пиротехнических источников электрического тока, устройства и системы пиротехнической автоматики.
\end{abstract}

\begin{abstract}
НИКОЛАЙ ВЛАДИМИРОВИЧ ПРУДНИКОВ - д.т.н., профессор, главный научный сотрудник Федерального государственного бюджетного учреждения науки «Межведомственный иентр аналитических исследований в области физики, химии и биологии при Президиуме РАН» (ФГБУН «МЦАИ РАН»). Область научных интересов: оптико-электронные системы и приборы.
\end{abstract}

\begin{abstract}
СЕРГЕЙ ВЛАДИМИРОВИЧ ГИЛЬБЕРТ - инженер-конструктор 1 категории АО «ФНПЦ «НИИ прикладной химии». Область научных интересов: малогазовые пиротехнические составы и технология формования зарядов на их основе для пиротехнических источников электрического тока, устройства и системы пиротехнической автоматики.
\end{abstract}

ДАРЬЯ СЕРГЕЕВНА ЗЮЗИНА - научный сотрудник АО «ФНПЦ «НИИ прикладной химии». Область научных интересов: малогазовые пиротехнические составы и технология формования зарядов на их основе для пиротехнических источников электрического тока.

141313 Сергиев Посад Московской области, ул. Акад. Силина, д. 3. Акционерное общество «Федеральньий научно-производственньй иентр «НИИ прикладной химии» (АО «ФНПЦ НИИ прикладной химии»), контакт. тел. (496) 548-09-71, факс (496) 549-90-91, E-mail: niiph@niiph.ru.

117342 Москва, ул. Профсоюзная, д. 65, стр. 6. Федеральное государственное бюджетное учреждение науки «Межведомственный центр аналитических исследований в области физики, химии и биологии при Президиуме Российской академии наук» (ФГБУН «МЦАИ РАН»), E-mail: mzairan@mzairan.ru.

Резервные источники тока в виде батарей высокотемпературных гальванических элементов, электроды которых выполнены из разнородных малогазовых энергетических конденсированных систем, иироко применяют для задействования и питания приборов и устройств различного назначения в экстремальных условиях. Применение тонкодисперсных модифицированных компонентов расширяет отечественную компонентную базу, сокращзает число контрольных операџий при улучшении технических характеристик источников тока и увеличении их стабильности, что свидетельствует об актуальности целенаправленного изменения структуры и свойств компонентов. Разработаны технологические процессы получения модифицированных продуктов и технические условия.

Ключевые слова: энергетические конденсированные системы, высокотемпературный гальванический элемент, резервный источник тока, модификация компонентов. 


\title{
ON THE POSSIBILITY OF EXPANSION OF THE DOMESTIC COMPONENT BASE OF CURRENT SOURCES BASED ON ENERGY CONDENSED SYSTEMS
}

\author{
V. V. Prosjanjuk ${ }^{1}$, I.S. Suvorov ${ }^{1}$, N. V. Prudnikov ${ }^{2}$, S. V. Gilbert ${ }^{1}$, D. S. Zyuzina ${ }^{1}$ \\ 13, Akademika Silina str., Sergiev Posad, Moscow region, 141313, Russia. Research Institute of applied chemistry. \\ 265, Profsoyuznaya Street, Moscow, 117997, Russia. Interdepartment Center of Analytical Research in Physics, \\ Chemistry, and Biology, Presidium of Russian Academy of Sciences.
}

Reserve current sources in the form of batteries of high-temperature galvanic cells, the electrodes of which are made of dissimilar low-gas energy condensed systems, are widely used to activate and power devices and devices for various purposes in extreme conditions. The use of finely dispersed modified components expands the domestic component base, reduces the number of control operations while improving the technical characteristics of current sources and increasing their stability, which indicates the relevance of a targeted change in the structure and properties of components. Technological processes for obtaining modified products and specifications have been developed.

Keywords: power condensed systems, high-temperature galvanic cell, reserve current sours, component modification.

В связи с расширением областей применения средств автономной электроэнергетики на основе малогазовых энергетических конденсированных систем (ЭКС), представляющих собой батареи высокотемпературных гальванических элементов (ВГЭ), способных функционировать в экстремальных условиях, в том числе при значительных отрицательных температурах в районах крайнего Севера и побережья Северного ледовитого океана, необходимость их разработки и совершенствования становится всё более актуальной [1-3]. Прямое преобразование химической энергии ЭКС в электрическую происходит в режиме горения тонких ( $1 \mathrm{Mм})$ многослойных зарядов, которые соединены между собой последовательно или / и параллельно тонкими (фольговыми) металлическими пластинами-токоотводами в батареи. Высокая температура в зоне окислительно-восстановительных реакций $\left(\sim 1500{ }^{\circ} \mathrm{C}\right)$, активные электродные материалы (окислитель и восстановитель), оптимальные рецептуры электродных композиций и конструктивные схемы ВГЭ и их батарей дают возможность получения необходимых значений напряжения и силы тока, времён активации и работы при минимальных габаритных размерах. Это обеспечивает практическую независимость электрических характеристик изделий от давления и температуры, механических нагрузок (удар, вращение, вибрации), пространственной ориентации и т.д. Батареи ВГЭ надёжно функ- ционируют как при разрежении (до условий открытого космоса), так и в объектах с избыточным давлением. Они характеризуются малым временем активации, простотой конструкции, любой геометрической формой изделий, высокой надёжностью работы, универсальностью по способу приведения в действие (от теплового инициирующего импульса любой природы, «нагретой стенки» и т.п.), возможностью дублирования огневых цепей электрическими и наоборот.

Степень соответствия технических характеристик источников тока современным и перспективным требованиям во многом определяется качеством компонентов ЭКС для обеспечения надёжного воспламенения и сгорания ВГЭ, а также генерирования электрического тока в экстремальных условиях применения.

Как известно, с 90-х годов XX века сырьевая и промышленная база отечественных компонентов претерпела глубокие изменения. Многие предприятия остались за рубежом, другие перепрофилировали своё производство, имеют морально и физически устаревшие основные фонды, выпускают продукцию опытными партиями, часто с отступлениями от стандартов качества. Конструкционные и активные электродные материалы для отечественных резервных источников тока не в полной мере соответствуют современным и перспективным требованиям, а технический уровень 
изделий по ряду показателей уступает лучшим зарубежным аналогам [4-7].

По этим причинам разработка и оптимизация технологий модифицирования отечественных компонентов и материалов стала одной из интенсивно развивающихся областей науки о материалах. Электрические характеристики батарей ВГЭ могут быть улучшены путем целенаправленного изменения (модифицирования) структуры и свойств компонентов ВГЭ. Например, электролит для ВГЭ из смеси фторидов металлов в эвтектическом соотношении имеет минимальную температуру плавления, а благодаря этому - обеспечивает быстрый выход на режим и максимальное время работы источников тока. Вместе с тем, формование электродных элементов ВГЭ по технологии вакуумного осаждения водной взвеси компонентов не позволяет в полной мере реализовать достоинства эвтектики, т.к. фториды металлов существенно различаются по плотности, размерам и форме частиц. По этой причине в каждом элементарном объёме водной взвеси и в сформованных изделиях соотношение частиц является случайным, что снижает стабильность характеристик ВГЭ и их батарей. Кроме того, фториды металлов содержат летучие примеси, снижающие точность определения эвтектического соотношения солей в композиции. Этим обусловлена необходимость получения нового компонента - порошкообразной фторидной эвтектики (ПЭФ).

Применение ПЭФ исключает расслоение фторидов в водной взвеси компонентов при формовании электродных элементов, улучшает и стабилизирует характеристики батарей ВГЭ. Внешний вид тонкодисперсных фторидов металлов, гомогенизированной механической смеси фторидов и ПЭФ приведён на рис. 1, 2.

Недостатками оксида меди (активного катодного материала), ухудшающими характеристики ВГЭ и их батарей, является низкое (до 91 \%) содержание основного компонента. Продукт даже квалификации «ЧДА» содержит оксид одновалентной меди, металлическую медь и примеси органических веществ. Тонкодисперсный окислитель адсорбирует азот, оксиды углерода и другие газы в значительном количестве. Летучие и органические примеси в компонентах ЭКС увеличивают объём газообразных продуктов при сгорании ВГЭ. Это оказывает отрицательное влияние на процессы воспламенения, безгазового горения и генерирования электрического тока. С газообразными продуктами из зоны горения выносится зна-

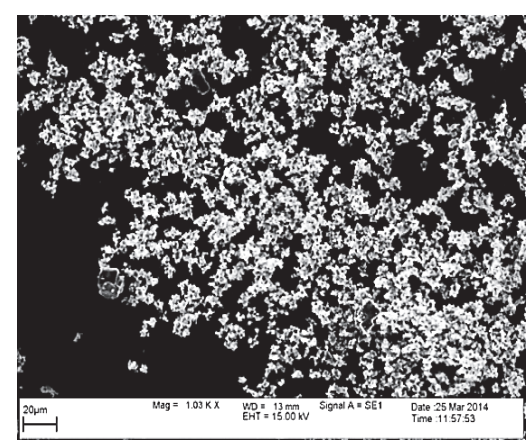

$a$

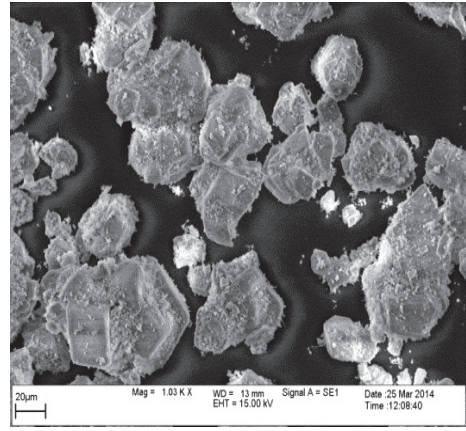

$\sigma$

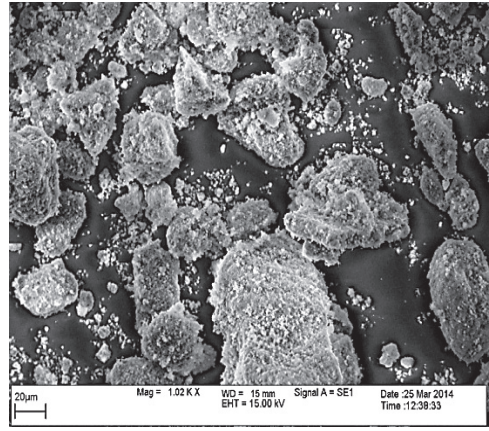

B

Рис. 1. Внешний вид исходных фторидов металлов

$a$ - фторид лития; б-фторид кальц̧ия; в) фторид магния

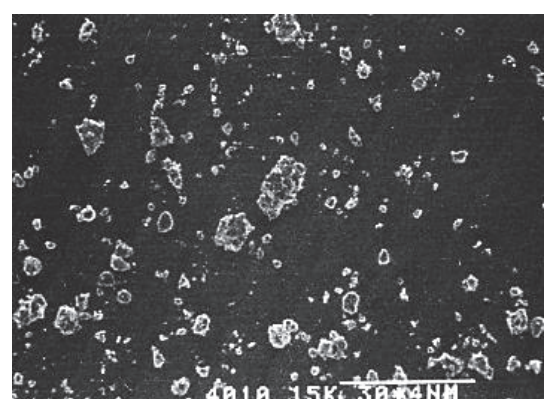

$a$

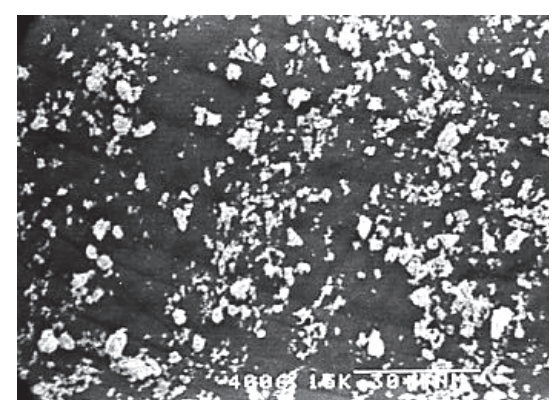

$\sigma$

Рис. 2. Внешний вид тонкодисперсных смесей

$a$ - гомогенизированная механическая смесь фторидов; б - фторидная эвтектика (ПЭФ) 
чительное количество тепла, что нарушает тепловой баланс, а также приводит к диспергированию продуктов сгорания и увеличивает их пористость, уменьшает скорость горения и её стабильность, ухудшает качество электрических контактов ВГЭ и их батарей. Это указывает на необходимость модификации окислителя и электролита.

Любой способ модификации в определённой степени активирует поверхность компонентов ЭКС. Например, плазмохимическая обработка обеспечивает глубокую поверхностную очистку и шлифовку поверхности любых материалов, но сопровождается частичным разложением оксида меди $[8,9]$.

Механическая обработка (в том числе механоактивация) порошкообразных композиций с целью получения гранул, содержащих компоненты в заданном (эвтектическом) соотношении, гарантирует гомогенизацию смесей практически на молекулярном уровне. Однако при этом из солей и оксида меди не удаляются летучие примеси, а полученные агломераты имеют низкую механическую прочность, что приводит к дезагрегированию при контакте с водой [10].

Анализ патентной и научно-технической литературы, а также проведённые исследования позволили установить, что оптимальным способом получения тонкодисперсной ПЭФ и модифицированного оксида меди является изотермическое термостатирование (прокаливание на воздухе) продуктов с последующим фракционированием. При этом удаляются адсорбированные газообразные и летучие примеси, происходит исправление дефектов кристаллических решеток, окисление низших оксидов и металлов и т.д.

Фториды металлов в эвтектическом соотношении перед термостатированием смешивали в вибромельнице для минимизации неравномерности распределения компонентов в объёме электролита. Гомогенизированную таким образом смесь фторидов металлов подвергали воздействию температуры $650{ }^{\circ} \mathrm{C}$ на воздухе. Конечный продукт представляет собой новый перспективный компонент для ВГЭ с температурой плавления $674{ }^{\circ} \mathrm{C}$. Экспериментально установлены оптимальная длительность термостатирования смеси фторидов (30 мин) и оптимальная удельная поверхность ПЭФ (7000-9000 см²/г). При выдержке тонкодисперсного ПЭФ при 95 \% относительной влажности воздуха в эксикаторе в течение 13 суток изменения массы не происходит, т.е. ПЭФ является не гигроскопичным продуктом. Увлажнение ПЭФ до $\geq 20 \%$ по массе, имитирующее технологию вакуумного осаждения водной взвеси компонентов, не сопровождается образованием кристаллогидратов и из-

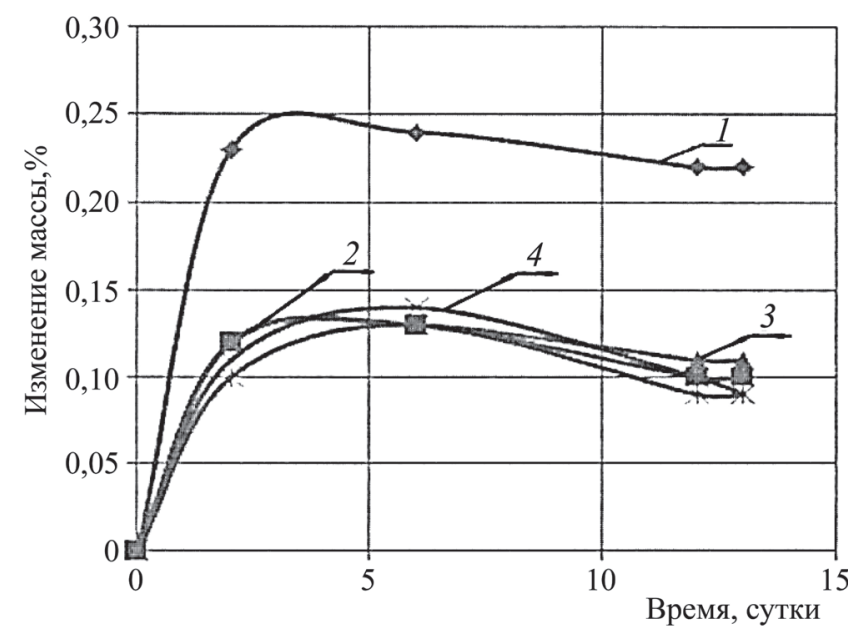

Рис. 3. Зависимость изменения массы образцов ПФА от длительности пребывания продукта при относительной влажности воздуха 90 \%

1 -масса 5,86 г, время спекания 15 мин;

2 - масса 13,45 г, время спекания 15 мин;

3 - масса 6,19 г, время спекания 30 мин;

4 - масса 12,62 г, время спекания 30 мин

менением массы продукта после высушивания. Зависимость изменения массы образцов ПФА от длительности пребывания продукта при относительной влажности воздуха $90 \%$ приведена на рис. 3 .

Как следует из рис. 3, ПЭФ является негигроскопичным компонентом. Анализ кристаллической структуры ПЭФ на дифрактометре с гониометром Rigaku Ultima IV показывает, что при модифицировании смеси фторидов происходят изменения межплоскостных расстояний и размера кристаллитов (зоны упорядоченности). Это свидетельствует о получении продукта с новыми свойствами.

Электролитный материал в ВГЭ представляет собой механическую смесь фторидов металлов или ПЭФ с порошкообразным диоксидом циркония (загустителем фторидного расплава). Его рентгенограмма приведена на рис. 4.

Как следует из рис. 4, загустителем электролитного материала является стабильная моноклинная фаза диоксида циркония. Сравнительные характеристики батарей ВГЭ с использованием механической смеси фторидов металлов и ПЭФ приведены на рис. 5.

Как следует из рис. 5, применение модифицированного электролитного материала позволяет стабилизировать характеристики батарей ВГЭ, что увеличивает надёжность работы источников тока и бортовой аппаратуры на их основе.

Модификацию оксида меди проводили термообработкой тонкодисперсного окислителя на воз- 


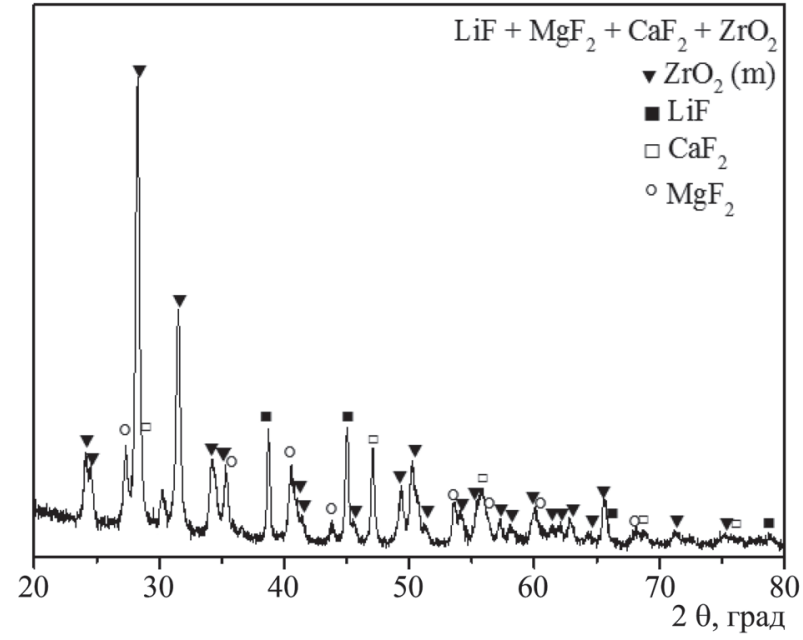

Рис. 4. Рентгенограмма электролитного материала на основе ПЭФ

духе для удаления органических примесей, окисления металлической меди и её одновалентного оксида при $850{ }^{\circ} \mathrm{C}$ с последующим контролем качества продукта. Следует отметить, что металлическая медь превращается сначала в оксид одновалентной меди, который с поверхности переходит в оксид двухвалентной меди. При этом образуется двухслойное оксидное покрытие (двухслойная окалина). В определённых условиях оксид одновалентной меди может диспропорционировать, а при продолжении процесса прокаливания практически полностью окисляется. Скорость реакций высокотемпературного модифицирования окислителя зависит от температуры, дисперсности частиц (исходной площади удельной поверхности порошка), доступности кислорода воздуха к обрабатываемому материалу (массы образца) и т.д. Рентгенограмма модифицированного оксида меди приведена на рис. 6.

Как следует из рис. 6, в модифицированном окислителе присутствует только оксид двухвалентной меди.

При модификации порошкообразного электролитного материала (смеси фторидов металлов) и оксида меди методом высокотемпературного термостатирования происходит удаление летучих примесей с низкой температурой кипения и влаги, окисление металлических примесей и соединений с низшей валентностью.

\section{Выводы}

Применение тонкодисперсных модифицированных компонентов ЭКС для резервных источников тока расширяет отечественную компонентную базу при улучшении технических характеристик батарей ВГЭ и увеличении их стабильности, что свидетельствует об актуальности целенаправленного изменения структуры и свойств компонентов ЭКС. Разработаны технологические про-
$\mathrm{U}, \mathrm{B}$

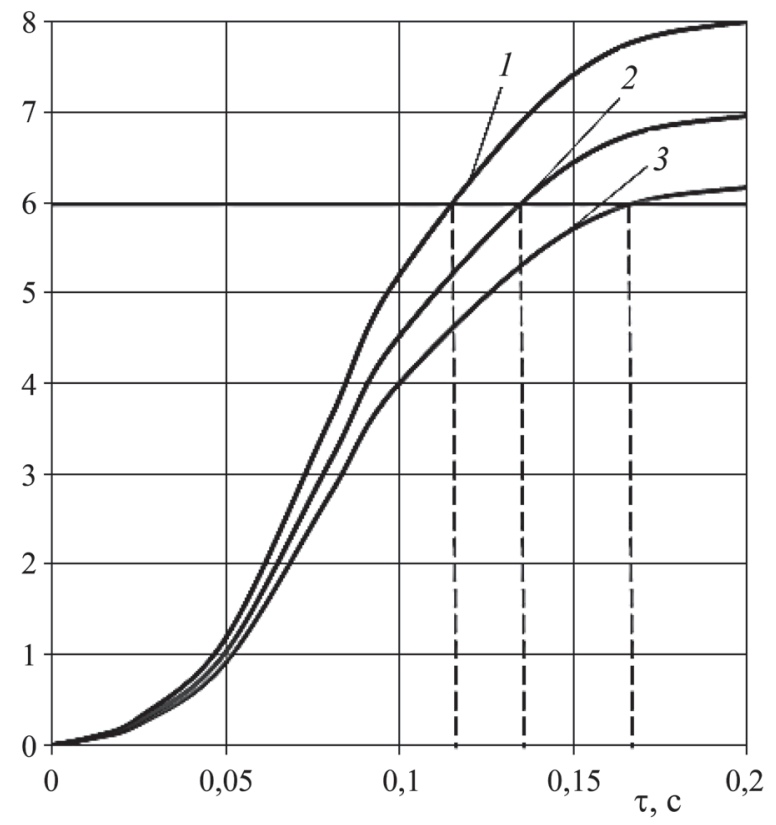

$\mathrm{U}, \mathrm{B}$

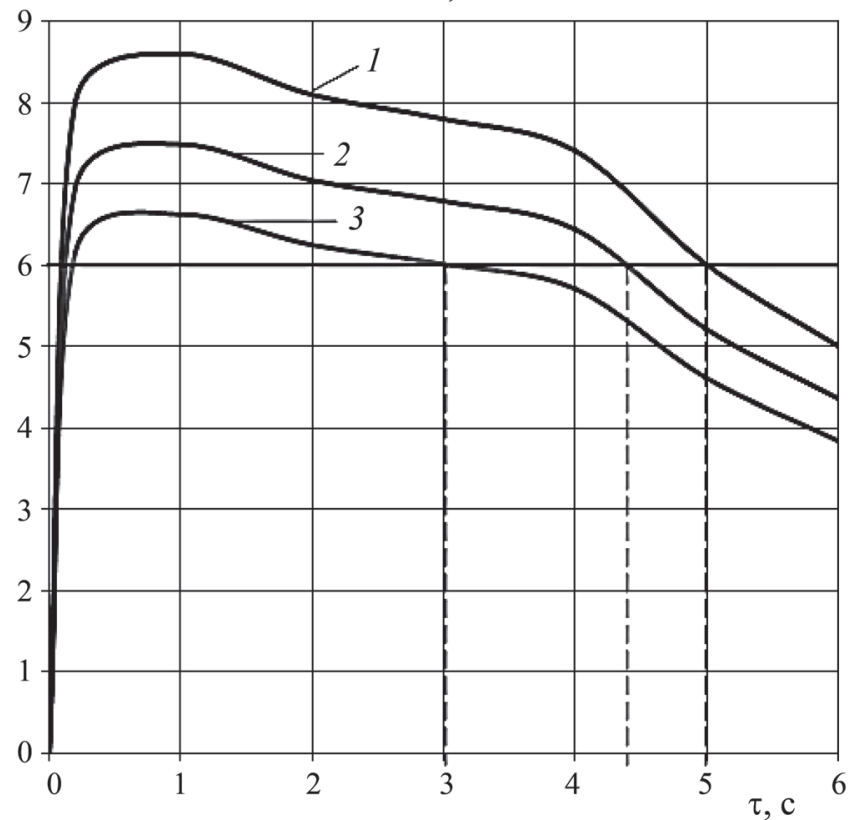

Рис. 5. Время активации а) и время работы б) батарей ВГЭ

1 -максимальные значения напряжения; 2 - минимальные значения напряжения (модифицированный электролит ПЭФ); 3 -минимальные значения напряжения (механическая смесь фторидов) 


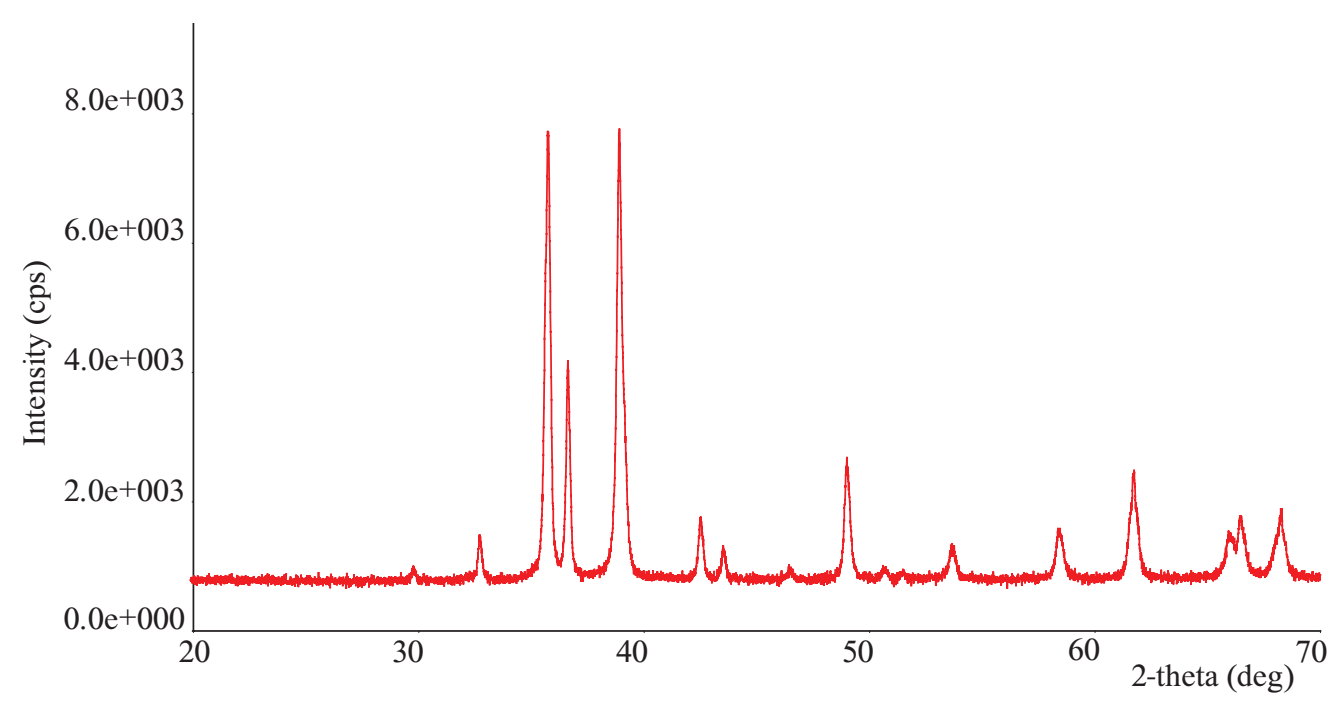

Рис. 6. Рентгенограмма модифицированного оксида меди

цессы получения модифицированных продуктов и технические условия.

\section{Литература}

1. Просянюк В.В. Суворов И.С. Парииков Б.Ю., Прудников Н.В. Нано- и микросистемная техника. 2020. №4. C. 220-227.

2. Просянюк В.В., Суворов И.С., Гильберт С.В. и др. Рос. хим. ж. (ж. Рос. хим. об-ва им. Д.И. Менделеева). 2016. Т. 60. №3. С. 10-19.

3. Вагонов С.Н., Просянюк В.В., Суворов И.С. и др. Избранные труды Всероссийской конференции по проблемам новых технологий. М.: РАН. 2015. С. 94117.

4. 75 лет $\mathrm{AO}$ «Энергия»: разработка и производство химических источников тока. Елец: АО «Энергия». 2016. $104 \mathrm{c}$.

5. Афанасьев А.С., Болдырев М.А., Халютин С.П. Электропитание. 2018. №1. С. 40-49.
6. Bagotskii V.S., Skundin A.M., Volfkovich Yu.M. Electrochemical power sources: batteries, fuel cells, and supercapacitors. New Jersey: John Wiley \& Sons. 2015. $375 \mathrm{p}$.

7. Payne Ju. L., Giagloglou K., Carins G. M. et. al. Frontiers in Energy Research. 2018. V. 6. P. 1-6.

8. Бурдикова Т.В. Плазмохимическая модификация порошков для энергонасыщенных конденсированных систем. Плазменные технологии исследования, модификации и получения материалов различной физической природы: сборник материалов Международной научной конференции. Казань: КНИТУ. 2012. 396 с.

9. Азаренков Н.А., Соболь О.В., Погребняк А.Д., Берсенев B.M. Инженерия вакуумно-плазменных покрытий. Харьков: ХНУ им. В.Н. Каразина. 2011. 344 с.

10. Белокрылова А.О., Матренин С.В. Механическое легирование порошков в условиях их обработки в планетарной мельнице. Новые материалы. Создание, структура, свойства-2013: сборник трудов XIII Всероссийской школы-семинара с международным участием. Томск: Изд-во ТПУ. 2013. 206 с. 